\section{Interdisciplinary and Multilevel Approach to Organic and Sustainable Agriculture Education at North Carolina State University}

\author{
M.S. Schroeder ${ }^{1}$, N.G. Creamer ${ }^{2}$, H.M Linker ${ }^{3}$, J.P. Mueller ${ }^{4}$, \\ and P. Rzewnicki ${ }^{5}$
}

ADDITIONAL INDEX WORDs. agroecology, land grant university, undergraduate, graduate, cooperative extension

SuMMARY. There is an increasing demand for education in organic and sustainable agriculture from undergraduates, graduate students and extension agents. In this paper, we discuss highlights and evaluations of a multilevel approach to education currently being developed at North Carolina State University (NCSU) that integrates interdisciplinary training in organic and sustainable agriculture and the related discipline of agroecology through a variety of programs for undergraduate students, graduate students, and extension agents. These educational programs are possible because of a committed interdisciplinary faculty team and the Center for Environmental Farming Systems, a facility dedicated to sustainable and organic agriculture research, education, and outreach. Undergraduate programs include an inquiry-based sustainable agriculture summer internship program, a sustainable agriculture apprenticeship program, and an interdisciplinary agroecology minor that includes two newly developed courses in agroecology and a web-based agroecology course. Research projects and a diversity of courses focusing on aspects of sustainable and organic agriculture are available at NCSU for graduate students and a PhD sustainable agriculture minor is under development. A series of workshops on organic systems training offered as a graduatelevel course at NCSU for extension agents is also described. Connecting experiential training to a strong interdisciplinary academic curriculum in organic and sustainable agriculture was a primary objective and a common element across all programs. We believe the NCSU educational approach and programs described here may offer insights for other land grant universities considering developing multilevel sustainable agriculture educational programs.

$\mathrm{F}$ or more than a decade, organic food sales in the United States and Europe have increased by approximately $20 \%$ annually (Nutrition Business Journal, 2004) and organic farming has become one of the fastest growing sectors of U.S. agriculture today (Dimitri and Greene, 2002). In 1999, U.S. organic food sales were estimated at $\$ 6.6$ billion and by 2010 sales could reach $\$ 45$ billion (Lohr, 2001). Increasing consumer demand for organic products and the growing awareness of sustainable agriculture are reflected in numerous U.S. Department of Agriculture (USDA) programs and

North Carolina State University, Raleigh, NC 27695

${ }^{1}$ Assistant Professor, Department of Crop Science.

${ }^{2}$ Associate Professor, Department of Horticultural Science.

${ }^{3}$ Professor, Department of Crop Science and Entomology.

${ }^{4}$ Professor, Department of Crop Science.

${ }^{5}$ Assistant Professor, Department of Horticultural Science. research initiatives in organic and sustainable agriculture, most importantly the establishment of the Sustainable Agriculture Research and Education (SARE) Program in 1988 and the $\mathrm{Na}$ tional Organic Program in 2002. The increasing importance of this sector to U.S. agriculture underscores the need for education and extension programs that focus on training in organic and sustainable agricultural practices.

Agricultural education must shift emphasis from teaching only how to maximize food production to incorporating environmental, social, and economic factors into the agricultural curriculum (Francis et al., 2003). Agroecology, which merges agriculture and ecology into a science of sustainable agriculture, provides the platform for the union of these disciplines using a holistic, problem-solving approach. Because the very nature of agroecology as a field of study draws on knowledge from multiple disciplines, including ecology, plant, soil, and animal sciences, a multidisciplinary and systems-level approach is required to integrate agroecology and sustainable agriculture into an agricultural curriculum (Altieri and Francis, 1992; Williams, 2001). Incorporating active learning exercises, hands-on training, and real-world problem solving across multiple fields in agroecology, sustainable and organic agriculture education will better prepare students and extension agents for solving the increasingly complex challenges facing our food system (Francis and Carter, 2001).

Land grant universities (LGUs) play a vital role in educating students and training extension agents in organic and sustainable agriculture. Incorporating research, education, and extension outreach into their missions, LGUs are uniquely qualified to educate at multilevels and train the nation's agricultural scientists, natural resource managers, farmers, and agribusiness leaders. Faculty from a number of LGUs have been leaders in developing agroecology and sustainable agriculture programs, collaborating across departmental lines to conduct the systems-level research needed to understand the complexity of interactions among the ecological, social, and economic factors in agricultural systems. Many agricultural universities recognize the importance of incorporating sustainable agriculture into the agriculture curricula (Borsari and Vidrine, 2005). The number of LGUs offering undergraduate and graduate programs addressing agroecology and sustainable agriculture are growing (e.g., Iowa State University, Michigan State University, NCSU, Ohio State University, University of California, Davis, University of Illinois, University of Maine, and University of Nebraska), yet are still few in comparison to traditional agronomy programs. Similarly, programs to train extension agents in organic and sustainable agricultural practices are sparse, despite a priority articulated in the 1990 Farm Bill to provide education in sustainable agriculture to extension faculty. Capitalizing on faculty expertise and research facilities in organic and sustainable agriculture, LGUs have the capacity to educate both students and extension agents in this area critical to the future of our food systems.

In this paper we describe a multilevel and interdisciplinary approach to education currently being developed at NCSU that integrates undergraduate, 
graduate student, and extension agent instruction and training in organic and sustainable agriculture through the discipline of agroecology. We present highlights of this approach, focusing on descriptions of a facility dedicated to sustainable and organic agriculture research, education, and outreach; the interdisciplinary faculty team that has developed these programs; and the curriculum development, activities, and training programs that support multiple levels of education in organic and sustainable agriculture at NCSU. One of the main goals of this multilevel instructional design was to link experiential training and an interdisciplinary academic curriculum in sustainable agriculture at a LGU. We believe the NCSU educational programs described here may offer insights for other LGUs considering a multilevel sustainable agriculture educational program.

\section{Methods and materials}

Training facility. The Center for Environmental Farming Systems (CEFS) was initiated in 1994 and is dedicated to research, education, and outreach in sustainable agriculture. The formation of CEFS was a direct result of a recommendation by a statewide sustainable agriculture task force (Mueller et al., 2002) that North Carolina's first priority should be to establish a largescale and interdisciplinary research and teaching facility that focused on sustainable agriculture. The resulting 2000 -acre facility $(\mathrm{l}$ acre $=0.4047 \mathrm{ha})$ located in Goldsboro, N.C., is a joint program between NCSU, North Carolina Agriculture and Technical State University (NCATSU), North Carolina Department of Agriculture (NCDA), farmers, and stakeholder groups.

The various educational programs described in this paper are made possible in part by the breadth of physical facilities at CEFS, allowing students and agricultural educators an expansive range of hands-on learning experiences and demonstrations. These facilities include a pasture-based dairy with cross-bred cows milked in an open air parlor, a beef cattle program for pasture-finished beef and alternative breed development, an alternative swine production system with four deep-bedded hoop houses, and 200 acres dedicated to a long-term, largescale farming systems experiment with comparative research on organic cropping systems, conservation tillage, forestry systems and integrated animal and crop systems, and organic research land with demonstration facilities. Central to agroecology and sustainable agriculture education for students was the establishment of an 11-acre student farm within CEFS. This student farm was designed specifically for the internship program (described below) to provide an area for students to explore sustainable agriculture practices.

The first goal of CEFS is to conduct education and outreach programs that engage students, agricultural professionals, and consumers. Through projects that forge connections between growers and consumers, CEFS works to promote the development of a regional food system that will improve North Carolina's food security while providing economic security for producers. The CEFS program emphasizes community-based food systems and alternative direct marketing strategies to targeted consumer groups (e.g., CEFS, 2005; Research Triangle Institute International, 2002), while also educating consumers about their role in facilitating a more sustainable agriculture through their purchase of local sustainable products.

In addition to the internship and apprenticeship programs described later in this paper, CEFS also hosts a range of farmer and extension agent training on a variety of pertinent sustainable agriculture topics. These have included but are not limited to pasture management, rotational grazing strategies, organic agriculture, disease management, organic grain production, conservation tillage, and composting. CEFS also hosts annual field days and other educational workshops.

The second goal of CEFS is to conduct research on technologies to create a cleaner and healthier environment. Projects under way at CEFS are aimed at helping producers enhance the efficiency and economic viability of animal enterprises using systems that reduce energy use, improve water quality, improve animal health, efficiently process animal waste, and improve the quality of life for producers. The 200 -acre long-term farming systems experiment at CEFS allows researchers the capacity to examine the impact of agriculture and natural areas on soil and water quality, carbon sequestration, pest dynamics, crop yield, economics, energy and nutrient flows, and biodiversity.
The third goal of CEFS is to provide new economic opportunities for North Carolina producers through alternative opportunities. Research and education about organic agriculture and alternative animal production systems are encompassed in this goal. Switching to organic production offers farmers the opportunity to maintain an economically viable farm business and poses opportunities for new rural enterprises. CEFS offers support for these farmers to create successful enterprises through research, education, and training on transitioning to organic crop and animal production practices, the marketing of organic products, and other related topics. In addition to the growing organic market, consumer demand for products such as pasture-raised meat, including turkeys, chickens, goats, beef, and hogs, is growing rapidly. CEFS is helping farmers interested in farm diversification to participate in this emerging market.

Collaborators. Motivated by growing environmental, social, and economic concerns about food production in the U.S., a group of faculty members at NCSU formed an interdisciplinary team representing researchers, educators, and extension specialists from the departments of animal science, anthropology and sociology, crop science, entomology, horticultural science, plant pathology, soil science, and statistics. Working together with faculty from NCATSU, members of this collaborative group advocated for the establishment of CEFS and designed and currently manage the long-term organic and sustainable agriculture research projects there. The establishment of the CEFS facilities laid the groundwork for the development of a comprehensive sustainable agriculture education program. Members of this CEFS interdisciplinary team collectively teach the sustainable agriculture summer internship program for undergraduates, mentor graduate students, and collaborate on organic and sustainable agriculture research topics.

UNDERGRADUATE EDUCATION: SUSTAINABLE AGRICULTURE SUMMER INTERNSHIP PROGRAM. The sustainable agriculture summer internship program was initiated in 1999 through a grant from the Z. Smith Reynolds Foundation and a USDA Higher Education Challenge grant. This intern- 
ship program provides undergraduate students with hands-on experiences in organic farm management linked with an interdisciplinary education in sustainable agriculture principles. Over 8 weeks, up to 20 students are exposed to various sustainable agriculture topics and participatory experiences through a diversity of inquiry-based learning methods, including classroom instruction and discussions, fieldbased activities, local farm field trips, faculty-mentored research projects, and organic farm production practices and marketing experience (Table 1 ). Each week, an interdisciplinary faculty team engages students in a variety of sustainable agriculture topics, such as integrated pest management, soil ecology and management, socioeconomics and marketing, and sustainable animal production through in-class lectures and field activities. Students apply these sustainable agriculture concepts and gain hands-on farming experience on a student-operated organic farm under the guidance of an experienced farm manager. The majority of activities in the internship program take place on the student farm, which primarily produces vegetables and small pasture-based livestock. Students are provided free housing within walking distance to the student farm. Each student works on a research project mentored by a faculty member in a specific area of sustainable agriculture throughout the internship program. Previous student research projects have included studies related to water quality, biological insect pest control, soil quality, rotational grazing, grassbased dairy, meat goat production, and compost production. On the last day of the internship program, each student presents the results of his or her study to fellow students, faculty members, graduate students, and local farmers. The strong linkage of the academic training, applied agriculture practices, and research experiences in the internship program provides students with a broad understanding of sustainable agriculture systems.
ApPrentiCeship In SUSTAINABLE AGRICULTURE PROGRAM. In addition to the internship program, NCSU offers a sustainable agriculture apprenticeship program. This program was designed for one to three individuals per year who prefer just the hands-on farming experience over a longer period (2-6 months). The apprentice works closely with the farm manager on the student farm and is involved in all aspects of sustainable crop production and animal management. Housing is provided and apprentices are paid a modest stipend to cover living expenses.

INTERDISCIPLINARY AGROECOLOGY MINOR. From the growing student interest in sustainable agriculture generated from the internship program, members of the interdisciplinary teaching team led the development of an undergraduate agroecology minor program in the Department of Crop Science in 2004. With an additional USDA Higher Education Challenge grant and a commitment from the College of Agriculture and Life Sci-

Table 1. Summary of topics and associated activities presented to students during the 8-week sustainable agriculture summer internship program occurring at the Center for Environmental Farming Systems in Goldsboro, N.C. In addition to the activities listed here, students also work on their faculty-mentored research projects each week.

\footnotetext{
Sustainable agriculture/agroecology

Lecture topic/discussions

Field activity

Farm management activities

Field trips

Integrated pest management

Lecture topic/discussions

Field activity

Farm management activity

Field trips
}

Soil management and soil ecology

Lecture topic/discussions

Field activity

Farm management activity

Field trips

Socioeconomics and marketing

Lecture topic/discussions

Field activity

Farm management activity

Pasture-based livestock systems

Lecture topic/discussions

Field activity

Farm management activity

Field trips

Permaculture

Lecture topic/discussions

Field activity

Agroforestry

Lecture topic/discussions
Overview of sustainable and organic agriculture

Compare vegetation and insect diversity among three agroecosystems

Introduction to student farm, overview of crops, harvesting

Canoe trip ${ }^{z}$, visit conventional and organic farms

Principles of integrated pest management, weed biology, pest ecology, biocontrol

Identify weeds, insects, and disease on student farm

Weed management on student farm

Visit conventional, organic farms and North Carolina State University Genome Laboratory (Raleigh)

Soil properties, ecology, and management

Examine soil properties and organism diversity on student farm, composting

Overview of tillage equipment, harvesting and planting

Visit two organic farms, observe cover crops, crop rotation, and nutrient management

Whole farm management, alternative marketing systems, discussion of fast food nation Visit two farmers markets and Central Carolina Community College (Pittsboro, N.C.) Harvest and sell crops from student farm each week

Overview of livestock, alternative pasture and agroforestry systems Examine beef and dairy pasture-based production systems, and pasture ecology

Care for and manage rotations of goats and chickens on student farm

Visit two dairy farms and a goat cheese operation

Permaculture concepts, discussion of visions for sustainable agricultural systems

Students design and construct bamboo structure within student farm

${ }^{\mathrm{z}}$ This initial activity was created so that students and faculty could connect external to the classroom. 
ences, a teaching assistant professor was hired to develop two new agroecology courses and coordinate this agroecology minor program. The primary goal of the agroecology minor is to provide students from all disciplines a fundamental understanding of agricultural systems from an ecological, economic, and sociological perspective.

The agroecology minor curriculum is structured to be interdisciplinary and provides students with opportunities for practical experiences in sustainable agriculture while offering a diverse array of courses. Students are required to take 11 credits comprising the Introduction to Ecology course and laboratory, the Introduction to Agroecology course, and the Advanced Agroecology course and laboratory. In addition, they must choose a minimum of six credits from at least two of three groups of courses categorized under ecology and agriculture production, social science, and economics (Table 2). Although the curriculum for this interdisciplinary program involves courses from 12 different departments, the agroecology minor program is managed from one crop science department. Administratively, centralization of management within a single department is preferred over multiple departments because the agroecology advisor can monitor curriculum changes, coordinate associated faculty, oversee the program webpage, and inform and advise students from one central location.

The two capstone agroecology courses, Introduction to Agroecology and Advanced Agroecology, were developed specifically for the agroecology minor program. These courses provide students with a strong foundation in agroecology while integrating concepts from multiple disciplines of crop science, animal science, ecology, plant biology, soil science, entomology, economics, and social science. Both agroecology courses emphasize developing students' oral and written communication skills, critical thinking, working in collaborative learning groups, and experiential learning though a variety of teaching strategies, using lectures, guest lectures, informal discussion groups, student-led discussion papers, peer review of student topic papers, and field trips to local farms. The Advanced Agroecology course has a laboratory section, allowing time for participatory experiences and examination of sustainable agriculture practices. Upon completion of this upper-level course and laboratory, students are expected to design a sustainable agricultural system describing the soil management practices, integrated pest management practices, crop selection and design, and nutrient budget model.
In this Advanced Agroecology course, students have access to small plots of land to experiment with crop selection, planting designs, and soil management practices.

A web-based, distance education section of the Introduction to Agroecology course was recently developed and taught for the first time in Fall 2005. Similar to the face-to-face section, the same types of teaching strategies and opportunities for student interactions were incorporated in this online agroecology course. Students receive lecture material through the form of lecture modules that integrate figures and photos with descriptive text and through a series of five video guest lectures. Students interact online with each other and the instructor as they lead discussions of case studies and articles, peer review each other's topic paper, virtually visit a local organic farm, and answer lecture discussion questions through the use of e-mail, discussion boards, videos, and chat rooms.

To increase students' global awareness of the challenges to organic and sustainable agriculture, students have the opportunity to participate in the Agroecology in Tropical America course in Costa Rica, a collaborative study abroad course between the University of Georgia and NCSU. Students

Table 2. Summary of undergraduate agroecology minor curriculum and courses at North Carolina State University, Raleigh.

\begin{tabular}{lcc}
\hline & Required courses (11 credits) & \\
\hline Introduction to Agroecology & Introduction to Ecology & Advanced Agroecology $^{\mathrm{z}}$ \\
\hline
\end{tabular}

Elective courses ( 6 credits)

Students must choose one course from at least two different elective groups below

\begin{tabular}{|c|c|c|}
\hline Ecology and agricultural production & Social science & Economics \\
\hline Introduction to Animal Science & Perspectives in Agricultural History & Environmental Law and Economic Policy \\
\hline Water Management & Environmental Ethics & Environmental Economics \\
\hline $\begin{array}{l}\text { Systems Approach to Agricultural and } \\
\text { Environmental Issues }\end{array}$ & $\begin{array}{l}\text { Sociology of Agriculture } \\
\text { and Rural Societies }\end{array}$ & U.S. Agricultural Policy \\
\hline Plant Life & Environmental Sociology & \\
\hline Plants and Civilization & Humans and the Environment & \\
\hline Crop Ecology & & \\
\hline Integrated Pest Management & & \\
\hline Insects and People & & \\
\hline General Entomology & & \\
\hline Conservation of Natural Resources & & \\
\hline Forest Ecology & & \\
\hline Soil Science & & \\
\hline
\end{tabular}


spend 3 weeks traveling to diverse biomes within Costa Rica, examining different agroecosystems and neighboring natural systems, interacting with local producers, and meeting an international team of researchers and students at two different agricultural universities [EARTH University and the Tropical Agricultural Research and Higher Education Center (CATIE)]. This international agroecology course is open to students from all disciplines, and agroecology students are encouraged to participate.

Throughout their courses in the agroecology minor program, students have many opportunities to interact with a diverse group of NCSU faculty with expertise in many aspects of agroecology and sustainable agriculture. Agroecology students are also encouraged to participate in research experiences mentored by faculty associated with CEFS. Although participation in the sustainable agriculture summer internship program is not required for the agroecology minor, it will be part of the interdisciplinary agroecology major that we are in the initial stages of planning.

Graduate education. At the graduate level, both MS and PhD stu- dents have the opportunity to design projects related to organic and sustainable agriculture and to collaborate with the interdisciplinary team of faculty associated with CEFS. Over 28 different graduate research projects to date have examined different aspects of sustainable and organic agriculture practices at CEFS (CEFS, 2004). All of these projects have resulted in completion of MS or $\mathrm{PhD}$ degrees or are in the process of completion. These graduate students have contributed to a total of nine refereed journal publications and have been awarded a total of $\$ 100,690$ in grant funding to date (Table 3 ).

Table 3. Summary of graduate student (MS and PhD) publications and grant funding from projects at the Center for Environmental Farming Systems in Goldsboro, N.C. Graduate students are listed in bold.

Refereed journal publications

Bertone, M., J. Green, S. Washburn, M. Poore, C. Sorenson, and D.W. Watson. 2005. Seasonal activity and species composition of dung beetles (Coleoptera: Scarabaeidae and Geotrupidae) inhabiting cattle pastures in North Carolina. Ann. Entomol. Soc. Amer. 98(3):309-321.

Bullock, L.R. and J.B. Ristaino. 2002. Effect of synthetic and organic soil amendments on southern blight soil microbial communities, and yield of processing tomatoes. Phytopathology 93(2):181-189.

Forehand, L.J., D.B. Orr, and H.M. Linker. 2006. Evaluation of a commercially available beneficial insect habitat for management of Lepidoptera pests in organic tomato production. J. Econ. Entomol. In press.

Millar, L.C. and M.E. Barbercheck. 2001. Interactions between endemic and introduced entomopathogenic nematodes in conventional-till and no-till corn. Biol. Control 22:235-245.

Millar, L.C. and M.E. Barbercheck. 2002. Effects of tillage practices on entomopathogenic nematodes in a corn agroecosystem. Biol. Control 25:1-11.

Reberg-Horton, S.C., J. Burton, D. Danehower, G. Ma, D. Monks, P. Murphy, N.N. Ranells, J. Williamson, and N.G. Creamer. 2005. Effect of time on the allelochemical content of ten cultivars of rye (Secale cereale L.).

J. Chem. Ecol. 31(1):179-193.

Seem, J., N.G. Creamer, and D.W. Monks. 2003. Critical weed-free period for 'Beauregard' sweetpotato

(Ipomea batatas). Weed Technol. 17:686-695.

Treadwell, D.D., D.E. McKinney, and N.G. Creamer. 2003. From philosophy to science: A brief history of organic horticulture in the United States.

HortScience 38(5):1009-1014.

Tungate K.D., D.J. Susko, and T.W. Rufty. 2002.

Reproduction and offspring competitiveness of Senna

obtusifolia are influenced by nutrient availability.

New Phytol. 154:661-669.
Grant funding

Forehand, L., D.B. Orr, and H.M. Linker. 2004. Evaluation of beneficial insect habitat for organic farms. U.S. Dept. Agr. (USDA), Southern Region, Sustainable Agriculture Research and Education (SARE). \$10,000.

Jelinek, S. 2003. Budweiser Conservation Scholarship. \$10,000.

Jelinek, S., J.P. Mueller, N.G. Creamer, M. Burton, and C. Brownie. 2003. Natural areas of vegetation and their influence on weed populations in neighboring fields. USDA, Southern Region, SARE. \$10,000.

McKinney-Finney, D. 2003. Moore N.C. Beautiful Fellowship. $\$ 10,000$.

McKinney-Finney, D. 2004. Budweiser Conservation Scholarship. \$10,000.

McKinney-Finney, D., N.G. Creamer, and M. Wagger. 2004. Can sorghum sudangrass grown as a summer cover crop for organic no-till vegetable production double as a cash crop for the organic hay market? Organic Farming Research Foundation. \$6,155.

Newman, M. and M. Barbercheck. 2000. Interactions between predators and insect-parasitic nematodes in soil. USDA, Southern Region, SARE. \$10,000.

Reberg-Horton, C., N.G. Creamer, and N. Ranells. 2001. Breeding a better cover crop: A screen of rye germplasm for weed suppression and nitrogen scavenging. USDA, Southern Region, SARE. \$10,000.

Treadwell, D. and N. Creamer. 2000. Evaluation of cover crops and conservation tillage for conventional and organic sweetpotato production in North Carolina. USDA, Southern Region, SARE. \$9,927.

Treadwell, D. 2004. Enhancement grant for follow-up work with organic sweetpotato study. USDA, Southern Region, SARE. $\$ 14,608$. 
There is a wide diversity of courses at NCSU in which graduate students interested in sustainable agriculture can enroll, including integrated pest management, biocontrol of insects and weeds, economics of world food and agricultural policy, soil ecology, sociological analysis of agricultural development, sociology of U.S. agriculture, rural sociology, advanced agroecology, organic horticulture, and topics in sustainable agriculture.

We recently proposed a $\mathrm{PhD}$ sustainable agriculture minor that would be a joint program between NCSU and Duke University, with NCATSU participating as a collaborating institution. A proposal is pending with $\mathrm{Na}$ tional Science Foundation to fund the initiative. By combining the expertise at NCSU and NCATSU in sustainable agriculture with expertise from Duke's Nicholas School of the Environment in ecology and environmental sciences, we seek to initiate an interdisciplinary program that can take a unique, in-depth, and interdisciplinary look at a range of sustainable agriculture issues. Our program is an attempt to merge the expertise of environmental scientists, ecologists, agriculturalists, economists, sociologists, and environmental ethicists to conduct integrative studies and full-cost accounting of agriculture systems.

The proposed sustainable agriculture minor will include combined 16-credit coursework from NCSU and Duke University, ensuring that PhD students will have the breadth of exposure to the ecological, economic, and social dimensions of agriculture. A new sustainable agriculture and ethics course is proposed in which the ethical issues surrounding sustainable agriculture will be integrated with a broad base of scientific topics. In addition, students will participate in study tours, collaborative group projects, a journal club, and bi-monthly seminars. An international component to students' projects will also be encouraged where applicable.

EXTENSION AGENT EDUCATION. In 1998, members of the CEFS interdisciplinary faculty team received a Southern Region SARE grant to conduct an organic systems training course for extension agents (Creamer et al., 2000). The interest among North Carolina farmers was growing and extension agents were in need of a variety of informational resources and experiences to help them be effective in answering questions from farmers. The training course included three goals: 1) increase extension's commitment to organic growers and the organic foods industry by expanding the knowledge base of extension agents in organic farming systems; 2 ) increase agent awareness and recognition that organic enterprises are viable farm enterprises in a growing agricultural industry; and 3 ) break down some of the existing barriers that prevent extension agents from working with organic growers. These barriers included an inadequate research database, limited experience with biologically based farming systems, discomfort in extending anecdotal information, and attitudinal barriers about organic growers and their motivation to be organic.

The organic systems training course focused on 14 components of organic farming systems, including fertility management; composting; insect, weed, and disease management; marketing; information delivery; greenhouse management; cover cropping; soil quality; crop rotation; tillage systems; integrated livestock systems; and farmer-to-farmer networking. These components were organized into six 2-d workshops. Agents attended the monthly sessions from April through September, and the training was offered as a four-credit graduate-level special problems course. The course consisted of lectures, demonstrations, hands-on activities, evening discussions, tours, field trips, and assignments, described in Table 4.

A key component of the workshops was the integrated and interdisciplinary approach to the teaching of organic production systems. While each workshop addressed specific components of organic systems, the component subject matter was placed within the context of an organic, wholefarm system. For example, rather than a simple discussion about the types of organic fertilizers available for use, educators provided information about how the application of these materials might affect weeds and other pests, soil quality, and farm economics. In addition to faculty from NCSU and NCATSU, teaching teams consisting of representatives from various nongovernmental organizations (NGOs), farmers, and other agriculture professionals also had key roles.

\section{Results and discussion}

UNDERGRADUATE AND GRADUATE EDUCATION. Since the undergraduate agroecology minor program was only recently implemented and the $\mathrm{PhD}$ sustainable agriculture minor is in the beginning stages of development, it is not possible to fully evaluate these programs at this point. The Introduction to Agroecology course has been taught for three semesters and student evaluations are very positive. Average course evaluations $(1-5,5=$ highest $)$ received were $4.58(\mathrm{SD}=0.67, \mathrm{n}=12)$ and $4.32(\mathrm{sD}=1.11, \mathrm{n}=19)$ for the first and second semesters the course was taught, respectively. This compared to the average evaluations for all courses in the Department of Crop Science of $4.43(\mathrm{sD}=0.82, \mathrm{n}=400)$ and $4.31(\mathrm{sD}$ $=0.98, \mathrm{n}=352$ ) during the same semesters these agroecology courses were taught. Students said they enjoyed the participatory learning activities, such as student-led discussion papers, peer review of fellow student term papers, and visits to local farms. Students from diverse majors have enrolled in the Introductory to Agroecology course, including agriculture education and extension, agronomy, animal science, botany, ecology, environmental sciences, environmental engineering, forestry, horticultural science, political science, and soil science. The agroecology courses and agroecology minor program is attracting a wide array of students to the agricultural sciences. Given their disciplinary backgrounds, many of these students would generally not enroll in an agricultural curriculum. For many of the students enrolled in the Introduction to Agroecology course, this was their first agriculture-related course. Because of students' varied academic backgrounds, learning styles, and expectations, special care is given to clearly explain and define concepts and to incorporate opportunities for students to interact and learn from each other.

Although only in its first semester, enrollment in the web-based section of the Introductory Agroecology course has similarly attracted students with diverse academic interests, including working professionals (such as a researcher from the National Resource Conservation Service and a local extension agent). We anticipate this online agroecology course will additionally be attractive to other specialists and 
Table 4. Summary of organic systems training course for extension agents (modified from Creamer et al., 2000). In addition to activities below, each 4-h workshop had a series of appropriate lectures presented by teams of researchers, extension personnel, farmers, or non-governmental organization participants. Workshops were combined in 2-d sessions as separated by lines in the table.

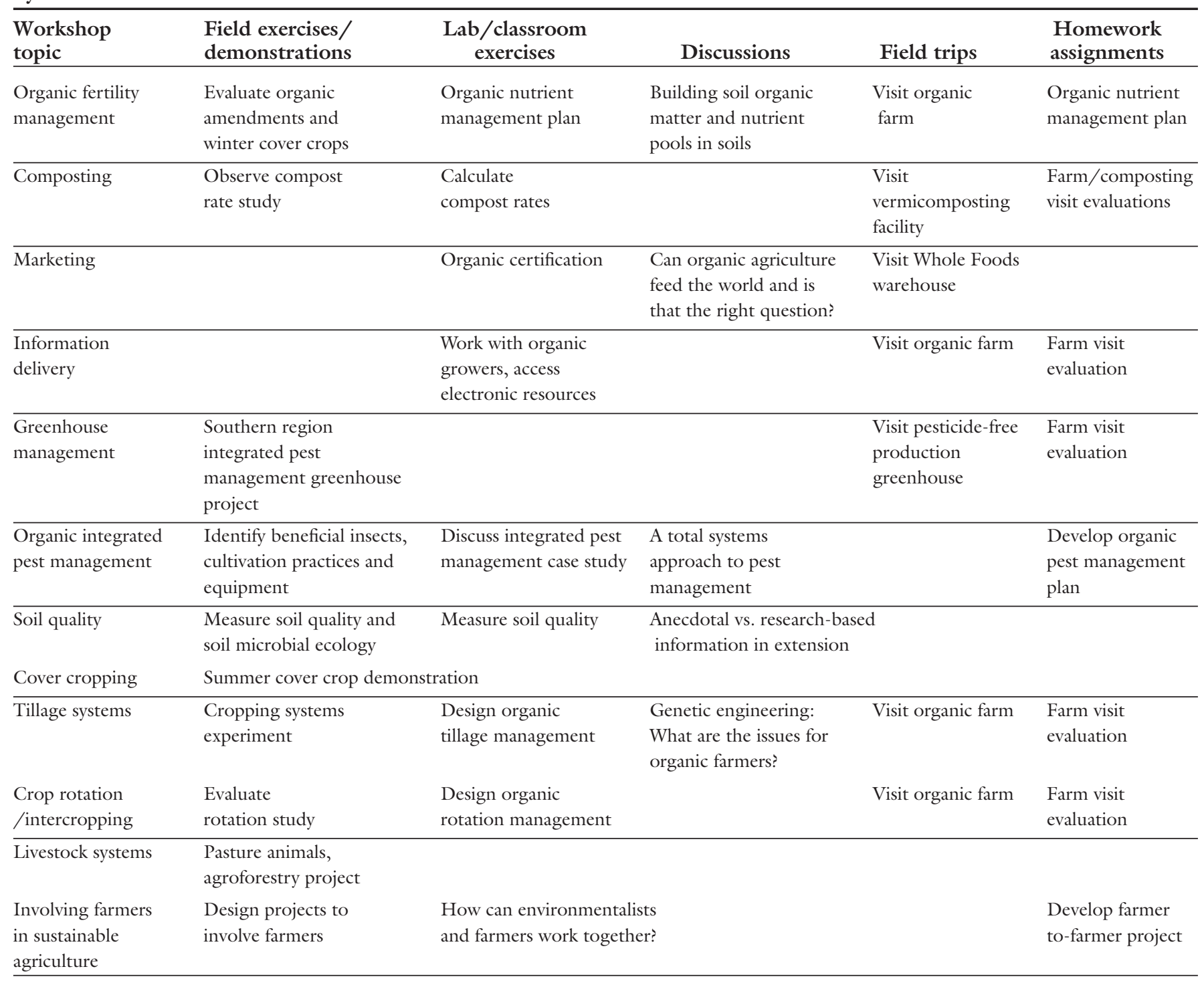

extension agents seeking training in agroecology and sustainable agriculture concepts. There are currently six students enrolled in the web-based Introduction to Agroecology course and all evidence suggests that interest in this online option will increase over time.

Currently in its sixth year, the sustainable agriculture summer internship program continues to attract up to 20 individuals per year (average per year $=16$ ) with varied interests, many from outside North Carolina (63\%) and some internationally (11\%). More than half of the interns (56\%) have not had any agriculture or related training, which may influence the future internship programming and curriculum design. At the end of each internship program, students are individually interviewed to assess course content, activities, and organization. The faculty teaching team uses these qualitative student evaluations to continually improve and enrich the sustainable agriculture internship curriculum. Students frequently comment that they enjoy working collaboratively on farm activities. The hands-on learning activities, being part of a working farm, and interaction with local producers on the farm visits are the components of the program most highly rated by students. Many students consider the research experience and interactions with faculty to be an important part of the internship program that they wouldn't have obtained from their general undergraduate curriculum.
After their intern research project experience, a few students have gone on to graduate programs with their faculty mentors.

Because of the wide range of student backgrounds in the internship program, one of the biggest challenges is to effectively teach at different levels of understanding. In any given group of students, there are some who prefer hands-on farming while others prefer more research experiences. Students often identify the balancing of lectures with farm work as a challenge. Faculty have responded by keeping in-class lecture time to a minimum and incorporating more discussion and hands-on field activities that complement lecture topics. Internship content and activities have been 
modified based on student evaluations from the previous year. For example, because of students' expressed interests in integrated pest management from the 2004 internship program, activities and in-class instruction on this subject were expanded from 1 to 2 weeks the following year.

EXTENSION AGENT EDUCATION. The organic systems training program was evaluated by agents as very successful. Thirty-two agents completed the course for graduate credit; an additional 10 attended regularly; and about 20 more attended at least one session. Evaluations showed that because of the basic focus on biological systems and interactions, almost every agent took away a body of relevant information that would be useful to them in a variety of different programs, even for conventional systems. There was an appreciation for the in-depth focus on topics, the hands-on nature of the training, and the interactions with organic farmers and NGO participants (Creamer et al., 2000).

The hands-on experience and farm tours gave the extension agents the opportunity to see or experience many of the sustainable agriculture principles they were learning about. Organic systems are information and management intensive, and the knowledge that organic growers possessed about their production systems impressed the extension agents. Many extension agents had never visited an organic farm. Growers appreciated the visits, valued the genuine interest demonstrated in learning about their operations, and indicated they will be less hesitant about working with extension agents in the future. There were other tangible benefits resulting from agent participation in the organic systems training program. Cooperating with growers in their counties, three of the agents in the class were awarded SARE producer grants (written as their final assignments) in 1999. Some have initiated organic training sessions in their counties. Twelve of the agents also participated in a statewide cover cropping demonstration in the Fall and Spring of 1998 and 1999.

Future Plans. Comprehensive evaluations and follow-up surveys are necessary to understand how these sustainable agriculture education programs will influence both students and extension agents. Regular reviews of the undergraduate and graduate edu- cational programs by students, faculty, and potential employers will provide valuable feedback for improving the curriculum, content, and teaching strategies. We believe the interdisciplinary training in agroecology and sustainable agriculture linked with opportunities for hands-on learning in the agroecology minor program and sustainable agriculture summer internship program at NCSU will prepare students for diverse careers, more than a traditional agronomy degree. Traditional agronomy majors will also benefit from agroecology education by associating with students from various backgrounds while experiencing a different view of production agriculture. By incorporating training in critical thinking and problem solving into these courses, graduates will be better prepared to solve complex challenges in our food system. We believe the next step is to examine the careers of graduates in sustainable agriculture and agroecology. From this data we can identify job opportunities, target potential employers, and refine our current agroecology minor curriculum and subsequently develop an agroecology major program that develops the specific skills these professions require.

We would like to provide further organic and sustainable agriculture educational opportunities at CEFS for extension agents and enhance their relationships with organic farmers. One such initiative is to expand participatory research practices that emphasize on-farm research activities connecting farmers with researchers, extension agents, and students. Currently, some faculty and graduate students at CEFS have a number of organic insect pest management studies on local farms; these could be expanded to additional areas of sustainable agriculture driven by farmer interests. The USDA SARE program is a necessary resource for $\mathrm{ex}^{-}$ tension agents and farmers interested in sustainable agriculture systems; it provides opportunities for producer grants and extension agent training unique to specific regions. North Carolina extension agents and producers have been very successful in the southern region in obtaining competitive grant funding for sustainable agriculture training and demonstration projects. During the past 10 years, more than 40 producer and professional development grants have been awarded to North Carolina producers and extension personnel.
The multilevel educational programs described in this paper demonstrates a successful approach for providing undergraduate and graduate students, and extension agents with a strong interdisciplinary education in sustainable agriculture linked with practical experiences in organic and sustainable agriculture practices. Land grant universities must respond to the growing student and extension agent interests in organic and sustainable agriculture and we hope the programs described in this paper stimulate ideas and similar movements at other LGUs.

\section{Literature cited}

Altieri, M.A. and C.A. Francis. 1992. Incorporating agroecology into the conventional agricultural curriculum. Amer. J. Alternative Agr. 7:89-93.

Bertone, M., J. Green, S. Washburn, M. Poore, C. Sorenson, and D.W. Watson. 2005. Seasonal activity and species composition of dung beetles (Coleoptera: Scarabaeidae and Geotrupidae) inhabiting cattle pastures in North Carolina. Ann. Entomol. Soc. Amer. 98(3):309-321.

Borsari, B. and M.F. Vidrine. 2005. Undergraduate agriculture curricula in sustainability: An evaluation across borders. J. Sustainable Agr. 25(4):93-112.

Bullock, L.R. and J.B. Ristaino. 2002. Effect of synthetic and organic soil amendments on southern blight soil microbial communities, and yield of processing tomatoes. Phytopathology 93(2):181-189.

Center for Environmental Farming Systems. 2004. Graduate student research at CEFS. 10 Feb. 2006. <http://www.cefs. ncsu.edu/cefsgradstudents.htm>.

Center for Environmental Farming Systems. 2005. North Carolina choices. 8 Feb. 2006. <http://www.ncchoices.com>.

Creamer, N.G., K.R. Baldwin, and F.J. Louws. 2000. A training series for cooperative extension agents on organic farming systems. HortTechnology 10(4):675-681.

Dimitri, C. and C. Greene. 2002. Recent growth patterns in the U.S. organic foods market. U.S. Dept. Agr. , Econ. Res. Serv., Agr. Info. Bul. No. 777.

Forehand, L.J., D.B. Orr, and H.M. Linker. 2006. Evaluation of a commercially available beneficial insect habitat for management of Lepidoptera pests in organic tomato production. J. Econ. Entomol. In press.

Francis, C.A. and H.C. Carter. 2001. Participatory education for sustainable 
agriculture: Everyone a teacher, everyone a learner. J. Sustainable Agr. 18(1):71-83.

Francis, C.A., G. Lieblein, S. Gliessman, T.A. Breland, N. Creamer, R. Harwood, L. Salomonsson, J. Helenius, D. Rickerl, R. Salvador, M. Wiedenhoeft, S. Simmons, P. Allen, M. Altieri, C. Flora, and R. Poincelot. 2003. Agroecology: The ecology of food systems. J. Sustainable Agr. 22(3):99-117.

Lohr, L. 2001. Factors affecting international demand and trade in organic food products. U.S. Dept. Agr., Econ. Res. Serv., WRS-01-1.

Millar, L.C. and M.E. Barbercheck. 2001. Interactions between endemic and introduced entomopathogenic nematodes in conventional-till and no-till corn. Biol. Control 22:235-245.

Millar, L.C. and M.E. Barbercheck. 2002. Effects of tillage practices on entomopathogenic nematodes in a corn agroecosystem. Biol. Control 25:1-11.

Mueller, J.P., M.E. Barbercheck, M. Bell, C. Brownie, N.G. Creamer, S. Hu, L. King, H.M. Linker, F.J. Louws, M. Marra, C.W. Raczkowski, D.J.Susko, and M.G. Wagger. 2002. Development and implementation of a long-term agricultural systems study: Challenges and opportunities. HortTechnology 12:362-368.

Nutrition Business Journal. 2004. The NBJ organic foods report 2004. Penton Media, San Diego, Calif.

Reberg-Horton, S.C., J. Burton, D. Danehower, G. Ma, D. Monks, P. Murphy, N.N. Ranells, J. Williamson, and N.G. Creamer. 2005. Effect of time on the allelochemical content of ten cultivars of rye (Secale cereale L.). J. Chem. Ecol. 31(1):179-193.

Research Triangle Institute International. 2002. CSA-About community supported agriculture. 8 Feb. 2006. <http://www. rti.org/csa/page.cfm?nav $=811>$.

Seem, J., N.G. Creamer, and D.W. Monks. 2003. Critical weed-free period for 'Beauregard' sweetpotato (Ipomea batatas). Weed Technol. 17:686-695.

Treadwell, D.D., D.E. McKinney, and N.G. Creamer. 2003. From philosophy to science: A brief history of organic horticulture in the United States. HortScience 38(5):1009-1014.

Tungate, K.D., D.J. Susko, and T.W. Rufty. 2002. Reproduction and offspring competitiveness of Senna obtusifolia are influenced by nutrient availability. New Phytol. 154:661-669.

Williams, D. 2001. Integrating sustainable agriculture into the classroom. Agr. Educ. Mag. 73(5):26-27. 